\title{
BERBAGAI MACAM TES UNTUK MENENTUKAN TINGKAT KESTABILAN SENDI LUTUT
}

\author{
Oleh: Bambang Priyonoadi , \\ Jur. PKR-FIK-UNY
}

\begin{abstract}
Abstrak:
Lutut mudah sekali terserang cedera traumatik. Persendian ini kurang mampu melawan kekuatan medial, lateral, tekanan, dan rotasi, karena lemahnya otot, dan mudah mendapat luka memar. Mekanisme datangnya cedera sendi lutut yang berakibat serabut ligamen utama dari lutut bisa menjadi putus bergantung pada aplikasi dari kekuatan, pukulan, tekanan, gerakan yang melebihi batas keregangan. Cedera ini dapat terjadi karena suatu gaya pada garis lurus (straigth line) langsung atau melalui bidang tunggal (single plane), atau karena suatu gaya berputar mendadak.

Luka akut dan kronis pada lutut dapat mengakibatkan ketidakstabilan sendi, lutut yang terluka diperiksa stabilitasnya secepat mungkin setelah cedera dan dilakukan hanya oleh tenaga yang sudah terlatih dan profesional. Lutut yang cedera dan lutut yang tidak cedera dites dan dikontraskan atau dibedakan untuk menentukan suatu perbedaan dalam tingkat stabilitasnya.

- Tes tekanan valgus dan varus dimaksudkan untuk menampakkan kelemahan kompleks kestabilan lateral dan medial, khususnya serabut ligamen colateral. Tes untuk menentukan integritas dari ligamen cruciate dapat dilakukan dengan menggunakan: 1) tes Drawer pada fleksi 90 derajat, (2) tes Drawer Lachman, (3) tes pivot-shift, (4) tes Jerk, dan (4) tes Drawer fleksi-rotasi. Untuk memastikan ketidakstabilan ligamen cruciate sebelah posterior dapat dilakukan dengan: (1) tesDrawer posterior, (2) tes recurvatum rotasi eksternal, dan (3) tes "Sag" Posterior. Adapun untuk menentukan meniscus yang robek dapat menggunakan tiga cara yaitu dengan: (1) tes McMurray, (2) tes kompresi apley, dan (3) tes distraksi apley.
\end{abstract}

Kata kunci: tes stabilitas sendi lutut 
Pada umumnya, anggota tubuh yang paling sering dikenai cedera pada waktu berolahraga adalah pada daerah sendi lutut. Cedera ini dapat terjadi karena sendi tersebut berfungsi melakukan pergerakan sambil menyangga tubuh (Elisson, A.E., dkk, 1986: 242). Pada setiap persendian, terdapat serabut-serabut otot yang menghubungkan tulang satu dengan tulang yang lainnya, serabut otot ini disebut ligamen, oleh karena itu cedera yang mengenai pada daerah ligamen ini sering disebut sprain. Sendi lutut dapat berfungsi untuk pergerakan dan untuk penyangga tubuh dikarenakan adanya beberapa jenis ligamen, serta sedikit tendo.

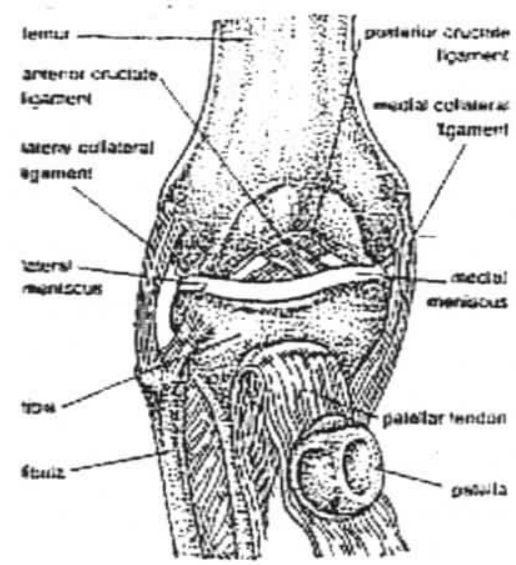

Gambar 1. Anatomi Persendian Lutut Dilihat dari Depan

(Sumber: Brukner, P., dan khan, K., Clinical Sports Medicine., 1993: 336)

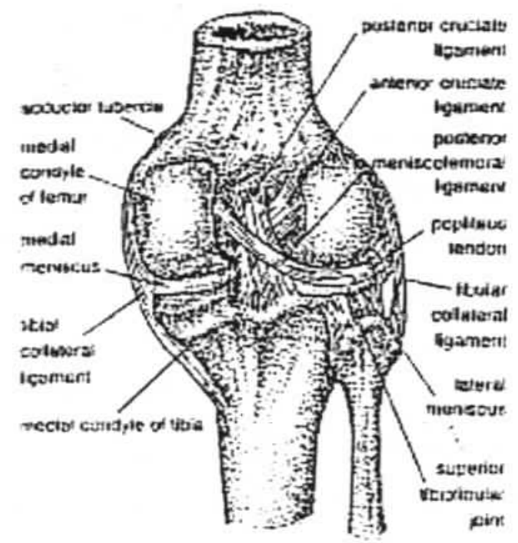

Gambar 2. Anatomi Persendian Lutut Dilihat dari Belakang (Sumber: Brukner, P., dan khan, K., Clinical Sports Medicine., 1993: 337) 
Lutut merupakan persendian yang besar dalam tubuh, lutut mudah sekali terserang cedera traumatik. Persendian ini kurang mampu melawan kekuatan medial, lateral, tekanan, dan rotasi, karena lemahnya otot, dan mudah mendapat luka memar (Arnheim, 1985: 544; Peterson, 1990: 286; Brukner, P., dan Khan, K., 1993: 336). Adapun mekanisme datangnya cedera sendi lutut yang berakibat serabut ligamen utama dari lutut bisa menjadi putus - baik putus secara terpisah atau kombinasi bergantung pada aplikasi dari kekuatan, pukulan, tekanan, gerakan yang melebihi batas keregangan - dan cedera ini dapat terjadi karena suatu gaya pada garis lurus (straigth line) langsung atau melalui bidang tunggal (single plane), atau karena suatu gaya berputar mendadak (Arnheim, 1985: 544). Semua gaya tersebut akan menimbulkan cedera pada bagian tengah ligamen colateral, bagian samping ligamen colateral, bagian berputar dari ligamen, bagian belakang ligamen cruciate, dan ligamen medial baik secara sebagian atau keseluruhan.

Cedera pada ligamen sprain menurut Sadoso (t.t.: 8) dan Brukner \& Khan (1993: 12) dibagi menjadi beberapa tingkatan, yaitu:

1. Sprain tingkat I. Pada cedera ini terdapat sedikit hematoma dalam ligamen dan hanya beberapa serabut yang putus.

2. Sprain tingkat II. Pada cedera ini lebih banyak serabut otot dari ligamen yang putus, tetapi lebih separoh serabut ligamen masih utuh.

3. Sprain tingkat III. Pada cedera ini seluruh ligamen putus sehingga kedua ujungnya terpisah.
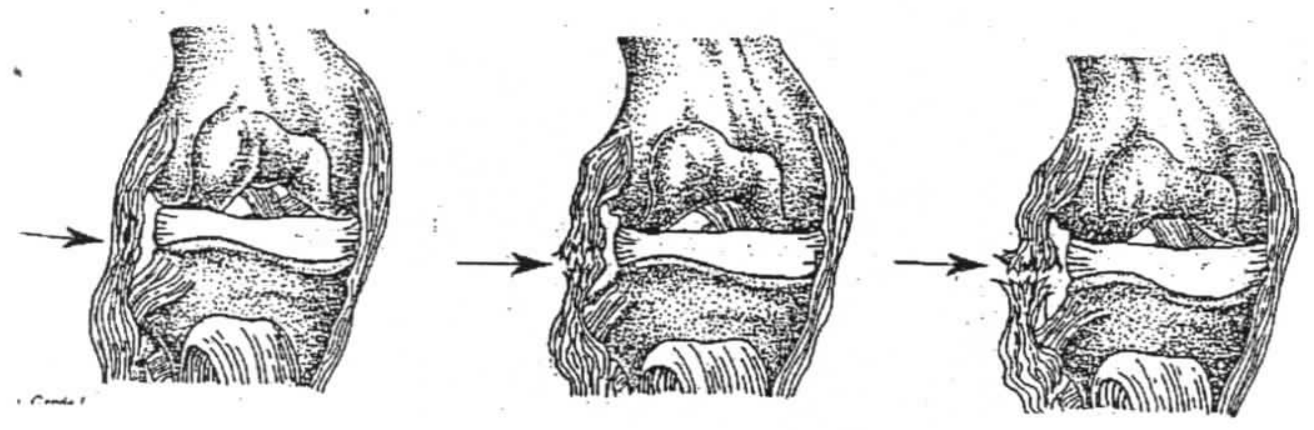

Gambar 3. Sprain Lutut Tingkat I, II, dan III

(Sumber: Brukner P., dan Khan, K., Clinical Sports Medicine., 1993: 12) 


\section{BEBERAPA TES UNTUK STABILITAS SENDI LUTUT}

Luka akut dan kronis pada lutut dapat mengakibatkan ketidakstabilan sendi. Disarankan bahwa lutut yang terluka diperiksa stabilitasnya secepat mungkin setelah cedera. Tes-tes seperti ini sebaiknya dilakukan hanya oleh tenaga yang sudah terlatih dan profesional secara baik. Lutut yang cedera dan lutut yang tidak cedera dites dan dikontraskan atau dibedakan untuk menentukan suatu perbedaan dalam tingkat stabilitasnya.

\section{Tes Tekanan Valgus dan Varus}

Gerakan valgus adalah gerakan ke sisi luar/samping (lateral), sedangkan gerakan varus adalah gerakan ke sisi dalam/tengah (medial) dari sendi yang terjadi secara mendadak. Tes tekanan valgus dan varus dimaksudkan untuk menampakkan kelemahan kompleks kestabilan lateral dan mediai, khususnya serabut ligamen colateral (Airnheim, 1993: 541).

A

B

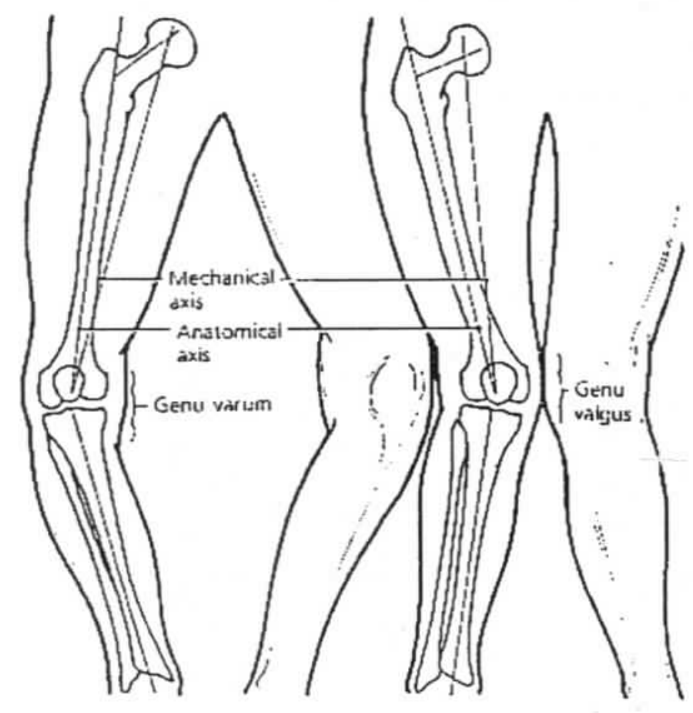

Gambar 4. A. Posisi Varus pada Sendi Lutut

B. Posisi Valgus Pada Sendi Lutut

(Sumber: Ellison, dkk., Atbletic Training and Sports Medicine., 1986: 237). 


\section{a. Pelaksanaan Tes Tekanan Valgus}

Pelaksanaan tes ini seperti diungkapkan Ellison, dkk. (1986: 341) dan Arnheim, D.D. (1993: 541) yaitu penderita berbaring telentang dengan kaki diluruskan. Untuk mengetes bagian medial, pemeriksa memegang pergelangan kaki secara kuat dengan menggunakan satu tangan, sambil meletakkan tangan yang lain pada kepala tulang fibula. Pemeriksa kemudian dengan kekuatan yang terukur menggerakkan lutut untuk membuka ke sisi samping sebelah luar, tekanan valgus diterapkan dengan lutut yang di ekstensikan secara penuh pada 0 derajat dan pada fleksi 30 derajat (gambar 5.A). Pengujian tes ekstensi penuh ligamen medial kolateral (medial collateral laterale/MCL) dan capsula posteromedial. Pada sudut fleksi 30 derajat ligamen medial kolateral $(M C L)$ adalah terpisah.

\section{b. Pelaksanaan Tes Tekanan Varus}

Posisi penderita berbaring telentang dengan kaki dilurcerran, sedangkan pemeriksa mengambil posisi badan dan pegangan kebalikan dari pemeriksaan tekanan valgus. Periksa dan lakukan tes ke samping lateral dengan daya varus pada lutut dan diekstensikan penuh, kemudian lakukan dengan fleksi 30 derajat (gambar 5.B). Dengan lutut diekstensikan penuh ligamen lateral kolateral (ligamentum lateral collaterale/LCL) dan kapsula posterolateral telah terselesaikan. Pada fleksi 30 derajat LCL adalah terpisah. Catatan: tungkai bawah akan di netralkan dengan tidak adanya rotasi internal dan eksternal (Ellison, dkk.,1986: 341 dan Arnheim, D.D., 1993: 541).

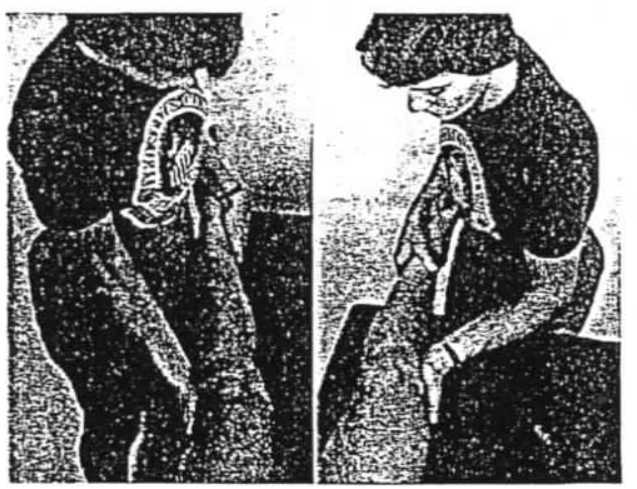

Gambar 5. Tes Tekanan Valgus dan Varus. A. Valgus. B. Varus (Sumber: Arnheim, D.D., Modern Principles of Atbletic Training., 1993: 541). 


\section{Tes Ligamen Cruciate anterior}

Arnheim (1993: 542) menyebutkan bahwa banyak tes baru-baru ini digunakan untuk menentukan integritas dari ligamen cruciate. Di antaranya ada tes Drawer pada fleksi 90 derajat, tes Drawer Lachman, tes pivot-shift, tes Jerk, dan tes Drawer fleksi-rotasi. Adapun penjelasan beberapa macam tes untuk menentukan integritas ligamen cruciate adalah seperti di bawah ini.

\section{a. Tes Drawer pada fleksi 90 derajat}

Cara kerja tes drawer pada fleksi 90 derajad (Arnheim, D.D., 1993: 541; Brukner P., dan Khan, K., 1993: 342) adalah penderita berbaring pada meja pelatihan dengan tungkai yang cedera difleksikan, sementara pemeriksa menghadap ke bagian depan tungkai penderita yang cedera, kemudian putar bagian atas tungkai dan sesegera mungkin di bawah sendi lutut dengan kedua tangan. Jari-jari pemeriksa diletakkan pada ruang atau tempat popliteal dari tungkai yang terafeksi, dengan ibu jari pada garis sendi medial dan lateral (gambar 6.A). Jari-jari lainnya dari pemeriksa terletak pada tendo bamstring, untuk memastikan itu semua, rilekskan sebelum tes dilaksanakan sebagai tata urutan kerja. Apabila ditemukan tulang tibia yang menggeser ke depan dari bawah tulang femur, dianggap tanda Drawer anterior yang positif. Jika tanda atau gejala Drawer anterior yang positif terjadi, tes sebaiknya diulang dengan tungkai atlet diputar secara internal 20 derajat dan diputar secara eksternal 15 derajat (gambar 6.B\&C). Penggeseran dari tulang tibia ke depan pada saat tungkai diputar secara eksternal adalah suatu indikasi bahwa bagian posteromedial dari kapsul sendi, ligamen cruciate anterior, atau kemungkinan ligamen bagian medial collateral mungkin terdapat robekan. Gerakan ketika tungkai dirotasikan ke arah internal diindikasikan bahwa ligamen cruciate anterior dan kapsul posterolateral mungkin terdapat robekan. 


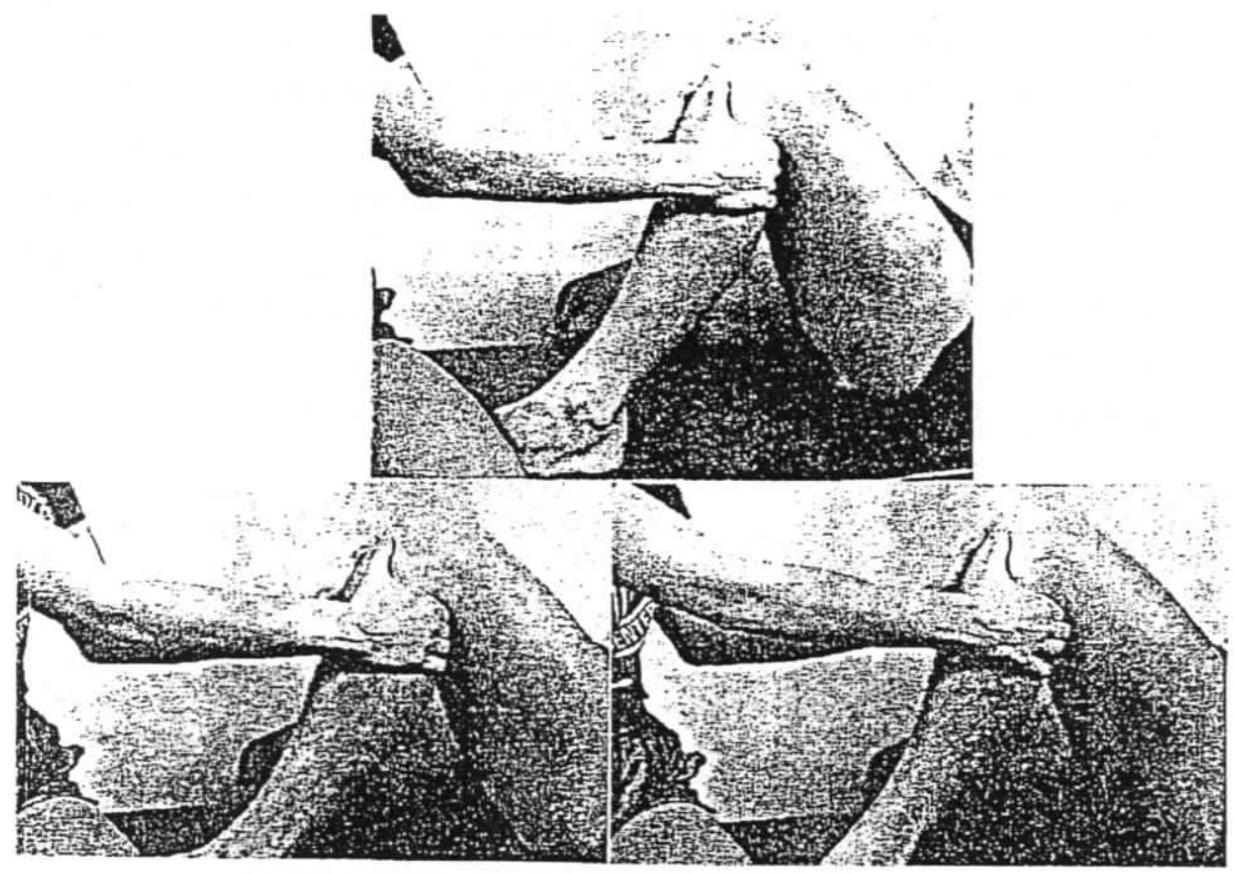

Gambar 6. Tes Drawer pada Cruciate laxity

A. Lulut pada sudut 90 derajat, dengan kaki pointing straight

B. Lutut pada sudut 90 derajat, dengan tungkai dirotasikan secara internal

C. Lutut pada sudut 90 derajat, dengan tungkai dirotasikan secara eksternal (Sumber: Arnheim, D.D., Modern Principles of Atbletic Training., 1993: 542).

\section{b. Tes Drawer Lachman}

Menurut Arnheim, D.D., (1993: 543) dan Brukner P., dan Khan, K., (1993: 342) pada tahun-tahun terakhir ini tes Drawer lachman telah menjadi lebih disukai oleh banyak orang karena adanya tes Drawer lachman pada fleksi 90 derajat (Gambar 7). Hal ini benar, khususnya untuk pemeriksaan segera setelah cedera, satu alasan untuk menggunakan tes tersebut segera setelah cedera adalah bahwa tes tersebut tidak memaksa lutut ke dalam posisi yang menyakitkan (sangat nyeri) pada sudut 90 derajat, tetapi mengetesnya lebih 
nyaman pada sudut 15 derajad. Alasan lain pada peningkatan popularitas tes ini adalah bahwa tes ini mengurangi kontraksi dari otot hamstring. Kontraksi tersebut menyebabkan kekuatan pensetabilan lutut sekunder cenderung untuk menutupi ekstensi yang nyata dari cedera. Tes Drawer lachman dikelola dengan meletakkan lutut pada posisi fleksi kira-kira dalam sudut 30 derajat, dengan tungkai diputar secara eksternal. Satu tangan dari pemeriksaan mestabilkan tungkai bawah dengan memegang bagian akhir atau ujung distal dari tungkai atas, dan tangan yang lain memegang bagian proksimal dari tulang tibia, kemudian usahakan untuk digerakkan ke arah anterior.

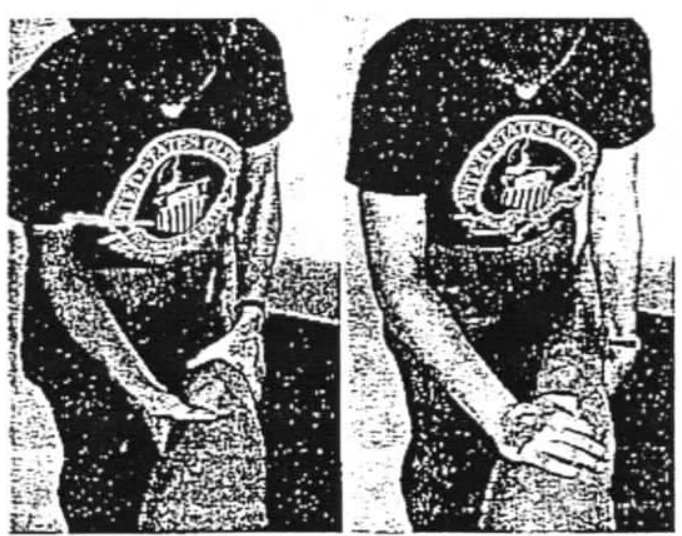

Gambar 7. A. Tes Drawer Lachman pada

Cruciate laxity, B. Metoda Alternatif

(Sumber: Arnheim, D.D., Modern Principles of Atbletic Training., 1993: 543).

\section{c: Tes Pivot-shift}

Tes Pivot-shift dirancang untuk menentukan ketidakstabilan putaran anterolateral (Gambar 8). Tes Pivot-shift paling sering digunakan dalam kondisi kronis dan merupakan tes sensitif pada saat ligamen cruciate bagian depan telah robek. Cara pemeriksaan adalah (Ellison, dkk., 1986: 238; Arnheim, D.D., 1993: 543) penderita berbaring telentang, salah satu tangan pemeriksa ditekan pada bagian kepala dari tulang fibula, tangan yang satunya memegang pergelangan kaki penderita tersebut. Untuk memulainya, tungkai bawah diputar secara internal dan lutut diekstensikan secara penuh. Tungkai atas kemudian difleksikan dengan sudut 30 derajat dari pinggul, saat itu lutut 
juga difleksikan dan daya valgus diterapkan oleh tangan bagian atas pemeriksa. Jika ligamen cruciate bagian anterior robek, maka tibia sebelah lateral tanpa ada kemajuan (tetap/"ajeg") akan disubluksasikan dalam posisi ini. Lutut difleksikan pada sudut 20 - 40 derajat tibia sebelah lateral tetap akan berkurang dengan sendirinya, ini berakibat menghasilkan palpable shift atau "clunk".

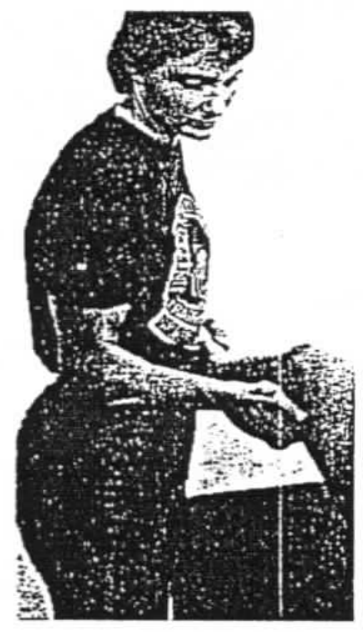

Gambar 8. Tes Pivot-shift pada Ketidakstabilan Putaran Anterolateral

(Sumber: Arnheim, D.D., Modern Principles of Atbletic Training., 1993: 543).

d. Tes Jerk

Cara pelaksanaan Tes Jerk (Arnheim, D.D., 1993: 544; Brukner P., dan Khan, K., 1993: 342) merupakan petunjuk sebaliknya dari pivot-shift. Posisi lutut diidentikkan sebagai penerimaan tes pivot-shift, lutut digerakkan dari posisi fleksi ke dalam ekstensi dengan tibia sebelah lateral tetap dalam penurunan posisi. Jika tidak cukup ligamen cruciate sebelah anterior sebagai gerakan ke dalam ekstensi tibia akan disubluksasi pada fleksi kira-kira 20 derajat, dan akhirnya menghasilkan sekali lagi palpable shift atau "clunk". 


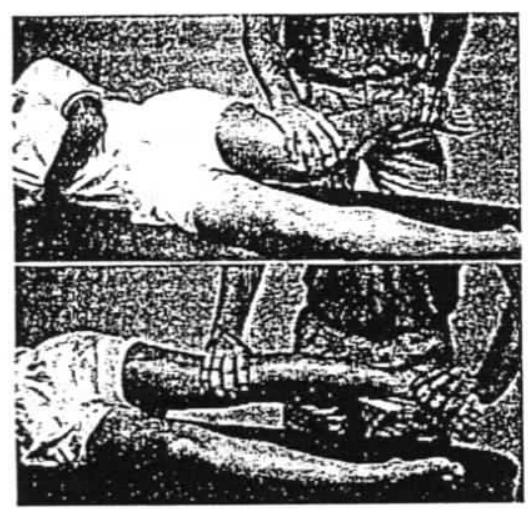

Gambar ソ. 1es Jerk pada Ketıdakstabuan rutaran Anterolateral (Sumber: Arnheim, D.D., Modern Principles of Atbletic Training., 1993: 544)

\section{e. Tes Drawer Fleksi-rotasi}

Arnheim, D.D., (1993: 544) melakukan tes ini dengan, tungkai bawah diayunkan dengan lutut difleksikan antara 15 dan 30 derajad. Pada sudut 15 derajat, tibia disubluksasikan ke arah anterior dengan femur dirotasikan ke arah eksternal. Lutut difleksikan ke sudut 30 derajat dan tibia diturunkan ke arah posterior dan kemudian femur dirotasikan ke arah internal.

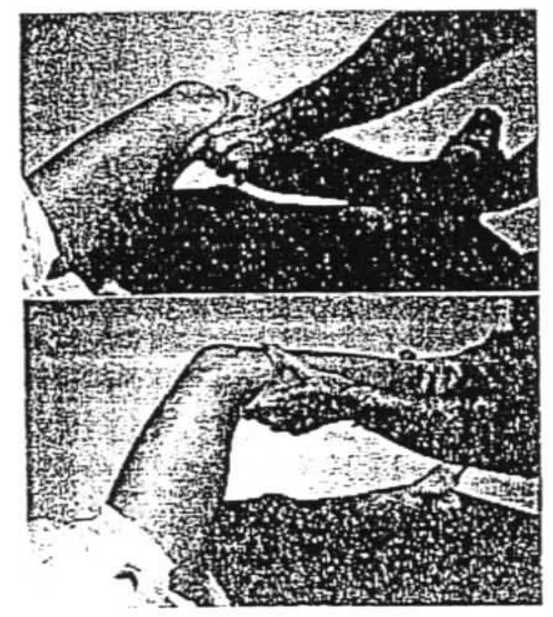

Gambar 10. Tes Drawer Fleksi-Rotasi

(Sumber: Arnheim, D.D., Modern Principles of Atbletic Training., 1993: 545) 


\section{Tes Ligamen Cricuate Sebelah Posterior}

Tes pada ketidakstabilan ligamen cruciate sebelah posterior dapat dikerjakan dengan beberapa cara di antaranya termasuk tes Draner Posterior, tes recurvatum rotasi eksternal, dan tes "Sag" Posterior. Adapun pelaksanaannya adalah seperti berikut di bawah ini.

\section{a. Tes Drawer Posterior}

Tes ini dibentuk dengan lutut difleksikan pada sudut 90 derajat dan kaki dalam keadaan netral. Daya digunakan ke dalam arah posterior pada proksimal tibia tanpa ada perubahan. Apabila terdapat Draner posterior positif maka dapat diindikasikan terjadi kerusakan pada cruciate posterior (Arnheim, D.D., 1993: 546; Brukner P., dan Khan, K., 1993: 343).

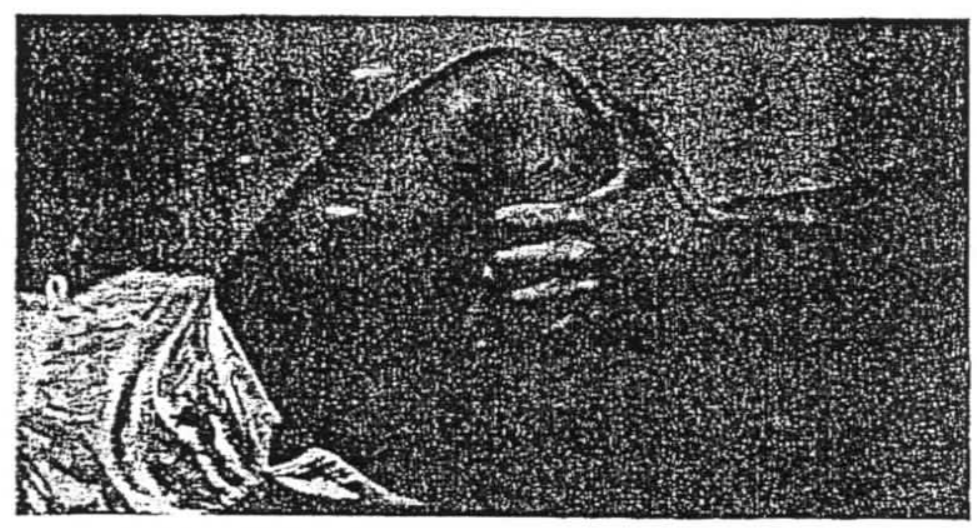

Gambar 11. Tes Drawer Posterior

(Sumber: Arnheim, D.D., Modern Principles of Atbletic Training., 1993: 545)

\section{b. Tes Recurvatum Rotasi Eksternal}

Penderita tidur telentang di meja pelatihan kemudian pemeriksa memegang jari-jari kaki dan angkat tungkai dari meja. Longgarnya posterior dan rotasi eksternal dari tibia mengindikasikan kerusakan pada ligamen cruciate posterior dan ketidakstabilan posteropateral (Ellison, dkk., 1986: 254; Arnheim, D.D., 1993: 546). 


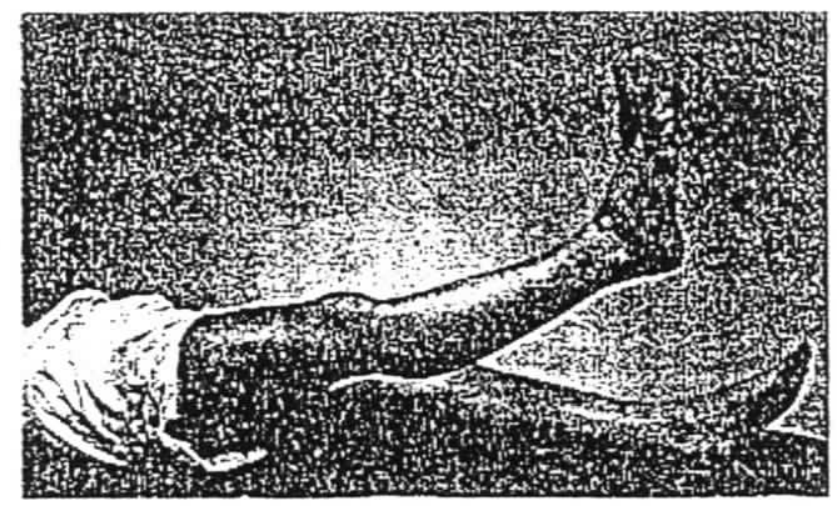

Gambar 12. Tes Recurvatum Rotasi Eksternal

(Sumber: Arnheim, D.D., Modern Principles of Atbletic Training., 1993: 546)

\section{c. Tes "Sag" Posterior}

Posisi penderita telentang di atas meja pelatihan, kedua lutut difleksikan pada sudut 90 derajat. Amati sisi lateral pada sebelah samping cedera, tibia akan nampak longgar pada sisi posterior ketika dibandingkan terhadap eksterimitas jika cruciate sebelah posterior mengalami kerusakan (Arnheim, D.D., 1993: 546) .

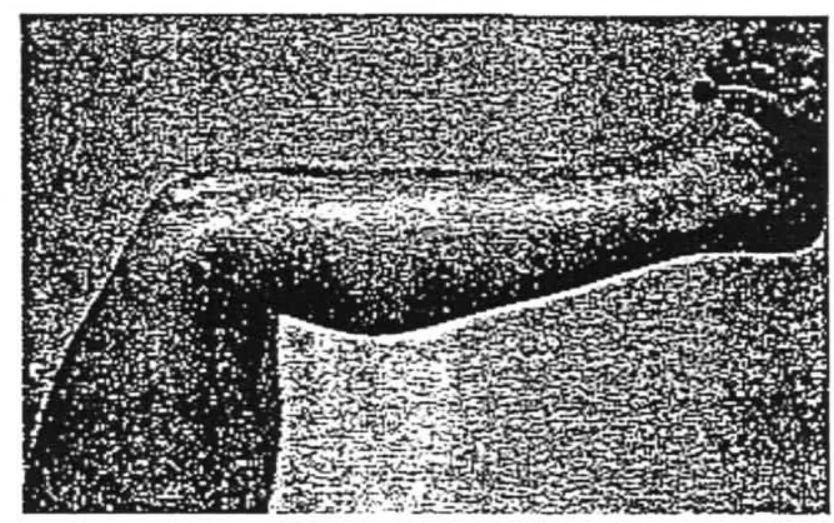

Gambar 13. Tes "Sag" Posterior

(Sumber: Arnheim, D.D., Modern Principles of Atbletic Training., 1993: 546) 


\section{Tes-tes Meniscus}

Pada umumnya, untuk menentukan meniscus yang robek para pemeriksa sering mengalami kesulitan. Arnheim (1993: 547) menjelaskan bahwa ada tiga macam tes yang paling umum digunakan yaitu Tes McMurray, Tes Kompresi Apley dan Tes Distraksi Apley.

\section{a. Tes Meniscal McMurray}

Tes McMurray (Gambar 20-17) digunakan untuk menentukan kehadiran badan atau tubuh yang lepas atau longgar pada lutut. Cara kerjanya adalah (Arnheim, D.D., 1993: 547; Brukner P., dan Khan, K., 1993: 343) penderita diletakkan menghadap ke atas di atas meja, dengan tungkai yang cedera difleksikan secara penuh. Pemeriksa meletakkan salah satu tangan pada kaki (telapak kaki) dengan tangan yang satunya di atas ujung lutut, jari-jari menyentuh garis sendi sebelah medial. Pergelangan tangan melakukan gerakan seperti menuliskan lingkaran kecil dan menarik tungkai ke dalam posisi ekstensi. Pada saat hal ini terjadi atau dilakukan, tangan pada lutut merasa ada respon bunyi "klik". Meniscus sebelah medial yang robek dapat dideteksi pada saat tungkai bawah diputar secara eksternal, sedangkan rotasi internal memberikan deteksi dari lateral yang robek.

\section{b. Tes Kompresi Apley}

Menurut Ellison, dkk. (1986: 247) dan Arnheim, D.D. (1993: 548) tes kompresi apley (Gambar 14) dilakukan dengan posisi penderita berbaring menghadap ke bawah (tengkurap) dan tungkai bawah difleksikan sampai 90 derajat. Sementara tungkai atas distabilkan, tungkai bawah segera diaplikasikan dengan tekanan ke bawah. Tungkai tersebut kemudian diputar kembali dan seterusnya. Jika rasa nyeri timbul, cedera meniscus terjadi. Tercatat bahwa terdapat robekan meniscus sebelah medial sewaktu dengan rotasi eksternal dan robekan meniscus lateral dengan rotasi internal tungkai bawah.

\section{c. Tes Distraksi Apley}

Pada posisi yang sama dengan tes kompresi apley (Arnheim, 1993: 548), pemeriksa menggunakan traksi pada tungkai saat menggerakkannya kembali dan seterusnya (Gambar 15). Maneuver ini membedakan robekan 
pada ligamen kolateral dari robeknya kapsul dan meniscus. Jika kapsul atau ligamen terpengaruh, rasa nyeri akan terjadi. Jika meniscus robek, tidak ada rasa nyeri yang terjadi dari traksi dan rotasi.

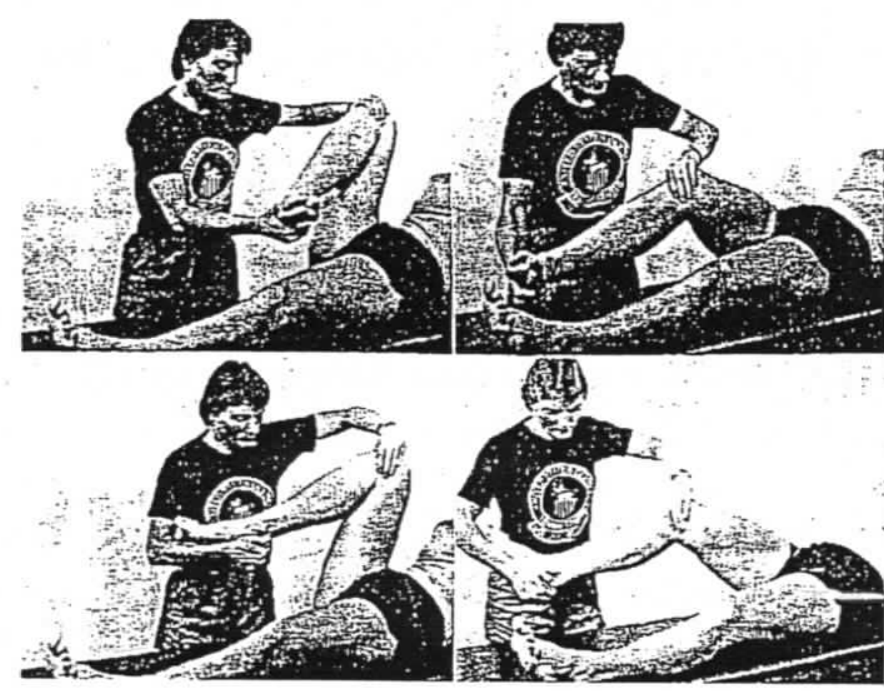

Gambar 14. Tes Meniscus McMurry

$A \& B$, Rotasi internal dari tungkai bawah ke ekstensi lutut

C\&D, Rotasi eksternal dari tungkai bawah ke eksternal lutut

(Sumber: Arnheim, D.D., Modern Principles of Atbletic Training., 1993: 548)

A

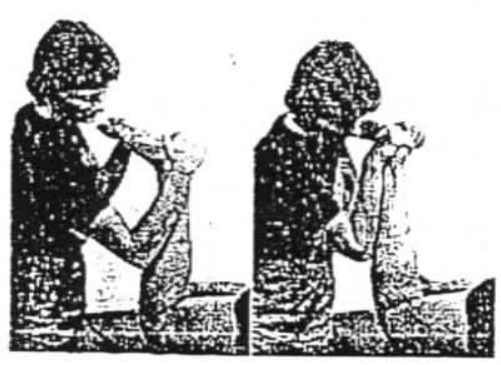

B

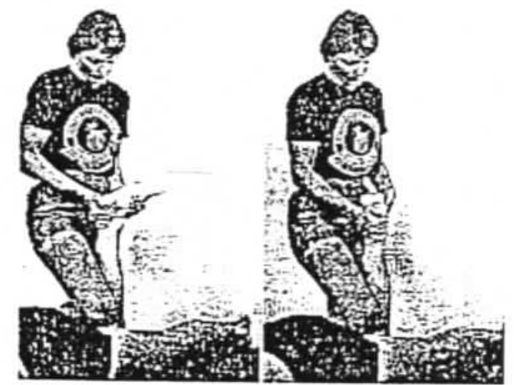

Gambar 15. A. Tes Kompresi Apley. B. Tes Distraksi Apley

(Sumber: Arnheim, D.D., Modern Principles of Atbletic Training., 1993: 549) 


\section{KESIMPULAN}

Luka akut dan kronis pada lutut dapat mengakibatkan ketidakstabilan sendi, lutut yang terluka diperiksa stabilitasnya secepat mungkin setelah cedera dan dilakukan hanya oleh tenaga yang sudah terlatih dan profesional secara baik. Lutut yang cedera dan lutut yang tidak cedera dites dan dikontraskan atau dibedakan untuk menentukan suatu perbedaan dalam tingkat stabilitasnya.

Tes untuk menentukan kelemahan kompleks kestabilan lateral dan medial, khususnya serabut ligamen colateral yaitu dengan tes tekanan valgus dan varus. Untuk menentukan integritas dari ligamen cruciate dapat dilakukan dengan menggunakan tes Drawer pada fleksi 90 derajat, tes Draver Lachman, tes pivot-shift, tes Jerk, dan tes Drawer fleksi-rotasi. Untuk ketidakstabilan ligamen cruciate sebelah posterior dapat dikerjakan dengan tes Drawer posterior, tes recurvatum rotasi eksternal, dan tes "Sag" Posterior. Adapun untuk menentukan meniscus yang robek dapat menggunakan tes McMurray, tes korireresi apley dan tes distraksi apley. 


\section{DAFTAR PUSTAKA}

Arnheim, D.D., (1985). Modern Principles of Atbletic Training. United State of America: Times Mirror/Mosby College Publishing.

Brukner, P., dan Khan, K., (1993). Clinical Sports Medicine. Australia: Mc.Graw-Hill Book Company.

Ellison, dkk, (1986). Atbletic Training and Sports Medicine. Illinois: The Academy of Orthopaedic Surgeon.

Sadoso, S., (t.t.). Cedera Olahraga di Arena. (t.k.). 